\title{
OM TO SLAGS VISMÆEND: DET ØKONOMISKE RÅD OG SOCIALISTISKE ØKONOMER ${ }^{1}$
}

\author{
Jens Henning Rasmussen
}

\section{»Dansk Økonomi«, april 1976}

Udgivelsen af rapporter fra Det Økonomiske Råds formandsskab er efterhånden ved at blive en kendt institutionaliseret begivenhed i det borgerlige Danmark på samme måde som orakelceremonierne var det i det antikke Grækenland.

I et lille rum bag scenen i templet i Delphi sad præstinden Pythia - datidens guddommelige råd - på en tre benet skammel og sniffede mystiske, euforiserende dampe, som steg op af en klipperevne. Når hun kom i ekstase tjente hun som formidler af Apollons vilje til den jordiske verden. Foran på tempelscenen blev hendes

1. Denne artikel er fremkommet som arbejdspapir i forbindelse med et gruppeprojekt på RUC om den danske akkumulations- og klassekampsudvikling fra verdenskrisen i 30'erne til den nuværende krise. Den konkrete sammenhæng i dette projekt er en gennemgang af Det Økonomiske Råds rapporter fra efteråret 1973 frem til aprilrapporten 1976 m.h.p. en påvisning af den nuværende verdenskrises nedslag i skiftende og selvopløsende forklaringsfors $\varnothing \mathrm{g}$ i den borgerlige $\emptyset$ konomiske diskussion. Dette har dannet udgangspunkt for en nøjere oparbejdelse af verdenskrisen i 30'erne og de internationale løsningsstrategier, udviklingen i den danske kapitalisme efter 2. verdenskrig, den nuværende internationale overakkumulationskrise frem mod en vurdering af de aktuelle kapitalistiske løsningsstrategier. Dette tænkes at munde ud i en diskussion af modsætningen mellem kapitalistisk og proletarisk arbejderbevægelse, d.v.s. en opregning af de konkrete forhold mellem på den ene side de spæde kimformer til en egentlig revolutionær selvorganisering i arbejderklassen og på den anden side de fremherskende inddæmningsstrategier, som udvikles af partier, fagbevægelse, arbejdsgivere og stat. 
ord videregivet af præsterne på vers og folk kunne så heri hente antydninger og nøgler til løsning af private og politiske problemer. Delphi-templet havde to indskrifter, som udtrykte de samfundsmæssige normer i den antikke verden: »kend dig selv« og »intet til overmål«.

Vores nuværende orakelinstitution består som bekendt af tre vismænd, som ad mystiske kanaler modtager kapitalens vilje og bud til de jordiske mennesker. ${ }^{2}$ Det ceremonielle består så i en messende sammenkomst af eksperter og repræsentanter for alle korporativt konspirerende organisationer i det borgerlige samfund, og resultatet bliver en stensikker medieschlager med omkvædet: »Og indkomstpolitik er iøvrigt den bedste løsning.«

I april 1976 kom så redegørelse nr. 29 - nr. 12 under titlen »Dansk Økonomi«. Som udsmykning til denne har man valgt et citat fra den gode gamle Adam Smith, som siger, at grundlaget for enhver nations rigdom og forbrug er den mængde arbejde, som nationens medlemmer yder - hvad enten de nu selv konsumerer deres eget produkt eller udveksler det med andre nationale arbejdsfællesskaber. ${ }^{3}$

Med denne henvisning til en central pointe i den klassiske, endnu seriøse borgerlige $\varnothing$ konomi søger vismændene dels at legitimere sig midt i deres apologetiske vulgærøkonomi: 'Vi bidrager til nationens rigdom med videnskabeligt arbejde', og dels at formulere kvintessensen af deres opfattelse af landets $\varnothing$ konomiske problemer: arbejdet er grundlaget for rigdommen og vi må derfor stræbe efter at bringe balance mellem ydelse og nydelse, produktion og forbrug, eksport og import etc., og »ikke leve over evne« eller afholde os fra »lønhamstring i utide«, som Arne Lund, DA, har udtrykt det.

Uden nærmere unders $\emptyset$ gelse af denne $\varnothing$ konomiske visdom skinner det sande indhold klart igennem: Det arbejde, som skaber en kapitalistisk nations rigdom, er lønarbejde. Hvad vismændene gør med den gamle liberalistiske autoritet i (h)ånden, er klart at slå fast, at hele vort forbrug - hvad enten det nu er hjemmeproduceret eller importeret, kontant afregnet eller taget på forskud - er baseret på dansk lønarbejde.

Selv om man, som traditionen er i Danmark, ikke udtaler tingene ved deres rette navn: lønarbejde, kapital, merværdi, profit, udbytningsgrad, profitrate etc., så er den væsentlige pointe i oraklet alligevel åbenlys. Selv om der måske nok i Danmark er et lidt specielt delingsforhold mellem den produktive kapital og forskellige trediepartnere, så er den vigtigste potentielle løftestang for en forøget akkumulation en forøgelse af udbytningen af lønarbejdet. Kun en forøgelse af

2. Man leder forgæves, hvis man ønsker kildehenvisninger til de oplysninger, som rapporterne vrimler med. Det kan derfor ikke bebrejdes undrende materialister, hvis de antager at formandsskabets spiritistiske evner som medie for kapitalens interesser skyldes telefonisk forbindelse til ministerier, nationalbank, arbejdsgiverforening, frimurer-loger samt venner og bekendte.

3. »The annual labour of every nation is the fund which originally supplies it with all the necessaries and conveniences of life which it annually consumes, and which consists always either in the immediate produce of that labour, or in what is purchased with that produce from other nations. « Adam Smith, »The Wealth of Nations«, 1776. Vismændene fejrer hermed også 200-årsjubilæet for den kapitalistiske produktionsmåde. 
den samfundsmæssige merværdimasse vil være en virkelig forbedring af profitmulighederne i den privatkapitalistiske konkurrence. Bedømmelsen af de mere specielle problemer omkring opretning af udenrigshandlen, opbremsning af inflationen, relativ nedskruning af en stor uproduktiv statsaktivitet, nedbringelse af arbejdsløsheden etc. må tage sit udgangspunkt i denne akkumulationslovmæssighed. Selvom aprilrapporten ikke å benbarer nogen erkendelse af disse sammenhænge i videnskabelig forstand, så udtrykker den dog en indrømmelse af, at den eneste kriseløsning er den, som dikteres af den private kapitals akkumulation. ${ }^{4}$ Oraklet foreskriver derfor, at de ansvarlige og handledygtige iværksætter en forøget udbytning, en forhøjelse af merværdiraten, en sænkning af den vægt hvormed arbejdslønnen indgår i produktionspriserne, af den relative lønomkostning eller på hollandsk: af bruttoreallønnen. ${ }^{5}$

Vismændenes aprilrapport $\mathrm{g} ø \mathrm{r}$ det endnu engang klart, at den eneste form for bevidst regulering af de samfundsmæssige forhold indenfor kapitalismen, som blot skal have en chance for at fremstå som virkningsfuld, er den som er nødvendig. Den abstrakte frihed, som vi ifølge den ideologiske statsfetichisme har til ad politisk vej »at forme vores verden «, kan kun realiseres når vi helt overgiver os til de kapitalsatte nødvendigheder. Den eneste mulighed for at få $\varnothing$ konomisk politik til at se ud som succesfuld, som fri politisk udøvelse af samfundskontrol, er at ophøje den kapitalistiske produktions og akkumulations lovmæssigheder til virkelige love, omsætte de økonomiske love til juridisk-politiske love. Politik under

4. Hermed ikke sagt, at vismændene ikke er fuld af feticherede forestillinger om disse sammenhænge og at de ikke forsøger at tilsløre karakteren af de politiske strategier, som de udstikker.

Der eksisterer selvfølgelig to afgørende nødvendigheder for en overvindelse af kapitalismens krise og igangsættelsen af et fornyet akkumulationsopsving: 1) forøgelse af udbytningsgraden af lønarbejdet, og 2) destruktion af kapital.

De særlige forhold og former, hvorunder overakkumulationen udvikles i den højtudviklede kapitalisme betyder imidlertid at udviklingen af politiske bevægelsesformer for kapitaldestruktionen indebærer en så afgørende forvandling af privatkapitalismen i statskapitalistisk retning, at dette falder helt uden for DØR's nuværende horisont. I den privatkapitalistisk orienterede borgerlige økonomi optræder denne side af den nødvendige kriseløsning endnu kun latent i vage programerklæringer om »strukturomlægninger « o.lign. - programmer som står milevidt fra at have noget at gøre med en destruktionspolitik.

5. Vismændene støtter sig i deres mere teoretiske begrundelse for indkomstpolitikkens nødvendighed på hollænderne Hartog, van de Klundert og Tjan: »Arbejdsløshed - art, omfang, strukturelle årsager og løsningsmuligheder «. For det hollandske Centralplanbureau har disse udviklet den bekvemme tese at forholdet mellem lønomkostningen og varens færdige markedspris forklarer alt. Begrebet »bruttorealløn« defineres netop som dette forhold, hvilket får vismændene til at affyre følgende:

»Den væsentligste størrelse i den nævnte teori er helt åbenbart reallønnen. En forringelse af den internationale konkurrenceevne som følge af en særlig høj inflationstakt er netop ensbetydende med, at reallønnen defineret som forholdet mellem lønomkostningerne og færdigvarepriserne i de respektive virksomheder er stærkt stigende i de sektorer af økonomien, der konkurrerer med udlandet.« (Dansk Økonomi, april -76 s. 56).

At den nominelt stigende arbejdsløn - »som følge af en særlig høj inflationstakt« - netop udtrykker et samtidigt fald i den virkelige realløn, en forarmelse af arbejderklassen, benægtes smukt gennem denne manipulation med reallønsbegrebet. 
kapitalismen kan derfor kun være en særlig bevægelsesform for akkumulationens nødvendigheder.

Den eneste måde, hvorpå en økonomisk politik derfor kan »løse« den nuværende krise, »nedbringe « underskuddet på betalingsbalancen, »afskaffe « arbejdsløsheden - altså fremstå som tilsyneladende subjekt for bevægelsen - er ved at anerkende lønarbejdet som grundlaget for produktionsudviklingen, merarbejdet som grundlaget for »klimaet « i den enkeltkapitalistiske konkurrence og profitmotivet som altafgørende for et fornyet opsving i akkumulationen. Ved at formulere indkomstpolitikken som mirakelkur for den danske $\varnothing$ konomi anviser vismændene således den eneste form for politik, som under de aktuelle forhold kan have udsigt til at fungere. Men at man i krisen og i stagnationen måske er i stand til fra statens side at udstikke strategier, som har kapitalnødvendigheden som indhold, betyder på den anden side ikke at politikken er garanteret; det afgøres i den privatkapitalistiske $\emptyset$ konomi, d.v.s. bl.a. af den spontane konkurrencegennemsætning af en adekvat kapitaldestruktion og den kapitalistiske arbejderbevægelses evne til at inddæmme og knuse arbejderklassens modstand.

\section{»Arbejdsløshed, betalingsbalance og økonomisk politik«}

er titlen på en rapport, som er udgivet i juli 1976 af »en arbejdsgruppe under Socialistiske Økonomer.«. Socialistiske Økonomer er en forening af såkaldte progressive »fagøkonomer« dannet i maj 1975. De offentliggjorde i efteråret 1975 et 11-punktsnotat i Politisk Revy nr. 274, hvori de redegjorde for deres syn på landets situation og det femkantede septemberforlig. Nils Bredsdorff huggede det ved samme lejlighed til pindebrænde og kaldte det meget rammende for »multiplikator-socialisme« baseret på en illusionsskabende overbudspolitik a la DKP. De er på det sidste blevet kendt som uforfærdede kritikere af augustforliget, som efter deres mening og regnefejl underst $\varnothing$ ttede kapitalismens sammenbrudstendenser.

Formålet med deres rapport er på den ene side at kritisere Det Økonomiske Råd og på den anden side at udstikke en alternativ, progressiv $\emptyset$ konomisk politik, PØР.

Umiddelbart kan man sige, at de Socialistiske Økonomer har ret i, eller virker overbevisende $\mathrm{i}$ deres påpegning af den manglende begrebsdefinition og klarhed $\mathrm{i}$ DØR's diskussion af konkurrenceevne og lønomkostninger. Men hvis man så søger en større klarhed hos dem selv (en mere konkret gennemgang følger nedenfor) går man forgæves. Det viser sig hurtigt, at S.Ø.'s justeringer og præciseringer helt igennem er den borgerlige $\varnothing$ konomis positivistiske overfladeanalyser. 
Mens man i DØR's vage diskussion om konkurrenceevnen og lønomkostninger klart fornemmer en vis sans for den kapitalistiske produktions væsentligste sammenhæng - eller modsætning: med et givent produktionsapparat forholder løn og profit sig omvendt proportionalt, så kaster de Socialistiske Økonomer sig over de mere konkrete forhold i den enkeltkapitalistiske konkurrence med en sådan fagøkonomisk kærlighed, at de almene og væsentlige bestemmelser forsvinder. Jo mere de vælter sig i det, som af en anden socialistisk ekspertgruppe: realanalytikerne kaldes niveauet for kapitalen i dens realitet, desto mere glemmer de (hvis de da nogensinde har haft det i deres fagøkonomiske hoveder) de grundlæggende bestemmelser og modsigelser i den kapitalistiske akkumulation. De falder i den forstand bag om det niveau, som kapitalens kårede vismænd besidder.

Selv om det er rigtigt at den konkrete prisdannelse i konkurrencen er en særdeles kompliceret og mangesidig proces, hvor forhold som produktivitet, renteniveau, jordpriser, fradragsregler, skatteprocenter, verdensmarked, valutaforhold etc. etc. spiller ind, så består en fornuftig kritik af DØR's vage forsimpling ikke i at give dem alle disse forvirrende konkretheder i hovedet. Tværtom kunne man næsten sige. Vismændene er sikkert ganske klar over de mangfoldige og konkrete momenter, som bestemmer den enkeltkapitalistiske prisdannelse. Men de er også klar over, at en vulgærpositivistisk detaljebehandling ikke er gennemførlig på det borgerlige, statistiske informationsgrundlag, som nu kan stables på benene. Videnskabeligheden består i en vis abstraktion, i en vis generalisering, hvor vismændene antager noget som mere afgørende end andet. Og her har de korrekt antaget modsætningen mellem arbejdsløn og profit som det mest afgørende.

En marxistisk kritik af vismændene må på det grundlag gå frem på den måde, at den påviser at de ikke er abstrakte nok ${ }^{6} \mathrm{i}$ deres forsimpling så at sige, at de ikke begriber modsætningen mellem lønarbejde og kapital, men kun arbejder på en legitimation af enkeltkapitalistens praktiske erfaringer. DØR må på det grundlag kritiseres for ikke at kunne redegøre for, hvordan den foreslåede lønsænkning kan tænkes at være løftestang for en forøget akkumulation, hvordan en lønsænkning kan tænkes at afstedkomme en industrialiseringsproces, som forbedrer handelsbalancen, hvordan dette afskaffer arbejdsløsheden, hvilke modsigelser der frembringes i en sådan udvikling o.s.v.

Men vores såkaldte Socialistiske Økonomer anser problemet helt anderledes. De anerkender ikke, at der i vismændenes upræcise og borgerligt formulerede konkurrencebetragtning skulle ligge noget rationelt, noget som udtrykker og tilsvarer et reelt væsensforhold i den kapitalistiske økonomi. Når vismændene ligesom deres klassiske forgænger Ricardo - taler om kapitalens rentabilitet på en

6. Jvf. Theorien über den Mehrwert, MEW 26.2. s. 167-68, hvor Bailey refereres for at have kritiseret Ricardo for at være for abstrakt, for at betragte værdi som noget immanent og absolut. Marx svarer med at sige, at Ricardo ofte ikke er abstrakt nok og at han mange gange glemmer den »absolutte værdi, som ligger bag bestemmelsen af de relative bytteværdier. Helt det samme gælder kritikken af folk som Say (jvf MEW 26.2. s. 440), som mente at Ricardo's abstraktioner var for kraftige. Marx siger her, at Ricardo ikke går vidt nok i den rigtige abstraktion og derfor bliver drevet ud i falske. 
sådan måde, at de reducerer alt til en omvendt proportionalitet mellem arbejdsløn og profit, så magter de socialistiske fag økonomer ikke at gennemskue, at der derved egentlig er tale om det bagvedliggende: merværdiraten og merværdimassen, hvoraf profit, rente, skatter etc. blot er forvandlingsformer. Når DØR anbefaler indkomstpolitik så opfatter S. Ø. det bare som et psykologisk udslag af instinktiv klasseondskab. Det er jo nu engang den herskende klasses beskæftigelse at undertrykke lønarbejderne. Da vismændene jo i Information vedkender sig at understøtte The Establishment så er det til at forstå. Men for os socialistiske fagøkonomer er det klart, at hele DØR's teori om lønnen som løftestang for akkumulationen er et tilrettelagt illusionsnummer. Se blot her venner, vi kan fremlægge en mere detaljeret statistik, som tilbageviser DØR's beregninger.

De Socialistiske Økonomer vil således tilbyde sig som et bedre orakelsvar og foreskriver, at vi lader kapitalen betale for løsningen af sin egen krise. De herrer kapitalister bedes høfligst hænge sig selv.

Hos S.Ø. kommer alt til systematisk at stå på hovedet. Alle modsætninger, strategier, kneb o.s.v. skal blot vendes om, betragtes fra den anden side, have et andet fortegn. Når kapitalen strejker skal vi tvinge den til at gå på arbejde. Når den strejker over hele verden skal vi tvinge den danske til at være strejkebryder. Vi skal blot fratage den den understøttelse, som den henter i braklægnings- og spekulationsgevinster. Beskæftigelse som lønarbejder under kapitalen er i virkeligheden et gode, beskæftigelsesgraden er så at sige arbejdernes profitrate. Kapitalens forrentning er i virkeligheden kun en slags aflønning, som vi yder den for at give os beskæftigelse. Vi må derfor skrue bisserne på og udbytte kapitalen noget mere, vi må tvinge den til at give arbejde til alle. Selektive tvangindgreb, tvangsinvesteringer, nationaliseringer om nødvendigt - arbejdernes statsdiktatur over kapitalen. Vi mindes Marx's kritik af den slags utopi: de vil gerne have kapitalen, men uden kapitalister.

S.Ø. har muligvis selv været klar over, at deres fagøkonomiske betragtninger intet har med socialistisk politik at gøre. I hvert fald erklærer de indledningsvis.

»at denne rapport forholder sig til den aktuelle økonomisk-politiske debat og ikke prætenderer at være led i arbejderbevægelsens diskussioner om veje for overgangen til socialisme.« (S.Ø. s. 4.)

Men det er faktisk værre end som så. S.Ø.'s interesse for »den aktuelle økonomiskpolitiske debat « i den borgerlige lejr er i sit væsentlige indhold udtryk for de statskapitalistiske og kontrarevolutionære tendenser, som udvikler sig med den stadig mere krisehærgede privatkapitalisme.

Den væsentlige tendens i det smækforvirrede forslag til en progressiv $\varnothing$ konomisk politik kan sammenfattes til, at når der ikke findes et kvalificeret borgerskab til at drive kapitalismen videre, så må vi fravriste det kontrollen over kapitalen, centralisere den i statslige organer og lade den forvalte af de kapitalistiske arbejderorganisationer. Den revolutionære arbejderbevægelse har allerede flere historiske erfaringer med sådanne forestillinger: den bolshevistiske inddæmning og knusning af den revolutionære sovjetbevægelse i Rusland gennem statskuppet i 1917, 
den fascistiske korporativisme i Italien og Spanien og det nazistiske partidiktatur i Tyskland.

S.Å. betegner intet andet end den akademiske intelligens' bestræbelser på at vinde universel og evig eksistensberettigelse. Stadig mere dekvalificerede og reducerede til viljes- og magtesløse objekter for udviklingstendenserne i den stagnerende privatkapitalisme anticiperer åndsarbejderne en mulig lederrolle som forvaltere og planlæggere i et statskapitalistisk samfund. Sammen med parti- og fagbevægelse udklækkes kunstfærdige planer for at inddæmme den stigende utilfredshed med den kriseramte privatkapitalisme og benytte et evt. opsving i den åbne klassekamp som springbræt for en magtovertagelse igennem det borgerlige parlaments legale kanaler. S.Ø.'s interesse for beskæftigelsessituationen er derfor yderst egoistisk og kontrarevolutionær i sit indhold: gennem en udskydelse af den selvorganiserede, arbejderkommunistiske ledelse og fordeling af produktion og forbrug bliver der plads til de akademiske fag $\varnothing$ konomer sammen med partifunktionærerne og fagforeningslederne i de statskorporative planbureauer.

M.h.t. S.Ø.'s modsætningsforhold til Det Økonomiske Råd er der altså kun tale om en strid om midler til overvindelse af kapitalismens krise. De fundamentale produktions- og klasseforhold skal opretholdes. Diskussionen finder derfor også sted helt på den borgerlige $\varnothing$ konomis grundlag. Det hører selvfølgelig til de positive sider, at DØR og andre af den borgerlige offentligheds profeter bliver modsagt og at specielt den tese, at dansk økonomi ene og alene skulle være hårdt trængt på grund af de ydre omstændigheder på verdensmarkedet, bliver tilbagevist. Men det må på den anden side også være en jubel for DØR og ligesindene, at de kan genkende uenighederne som en gammel traver: 'realistisk' neoklassicisme og 'progressiv' venstrekeynesianisme. Vi ser de gamle, erfarne rotter mod deres idealistisk fremturende yngel. ${ }^{7}$

Jeg vil i det følgende gennemgå de Socialistiske Økonomers rapport mere indgående. Deres kritik af DØR samler sig om fire punkter:

1. begrebet »Konkurrenceevne«,

2. lønberegningerne,

3. begrebet $\gg$ Strukturarbejdsløshed $\ll$ og

4. indkomst- eller lønpolitikken.

\section{Begrebet »Konkurrenceevne«}

»Ordet konkurrenceevne anvendes ofte, og tilsvarende sjældent gives det en præcis betydning. Vi vil også afstå fra en præcis definition, men til gengæld hér diskutere, om man kan tale om lønudviklingen næsten som synonymt med udviklingen

7. Se f.eks. Information d. 21.10. og 26.10., hvor Alexander Schaumann fra Det Økonomiske Råds sekretariat lige vil påpege det utilstrækkelige og delvis inkonsistente grundlag for det ellers »i mange henseender udmærkede progressive program $\ll$. 
i konkurrenceevnen, sådan som DØR's rapport fra april 1976 faktisk gør det.« (S.Ø. s. 8).

Nu er det bare sådan, at man ikke kan afgøre spørgsmålet om hvorvidt lønudvikling og udvikling i konkurrenceevne er identiske eller ikke-identiske uden på en eller anden måde at bestemme indholdet i termerne. Eftersom S.Ø. vil afstå fra en præcis definition må vi derfor nøjes med en upræcis definition:

»Det er klart, at konkurrenceevne har noget at gøre med virksomhedernes evne $o g$ vilje til at fastholde og eventuelt udvide deres markedsandele såvel på eksportmarkederne som på hjemmemarkedet $\mathrm{i}$ konkurrence med udenlandske virksomheder.«(S.Ø. s.8).

Med en smule mere præcission kunne man have sagt, at konkurrenceevnen må være en bestemmelse ved virksomheden, som fremtræder i dens fastholdelse, udvidelse eller tab af markedsandele. (På samme måde som åndsevner kommer til udtryk i fag økonomiske betragtninger uden at være identisk med dem). Man ville så være godt på vej mod en fornuftig forskning og analyse.

Men de Socialistiske Økonomer nøjes med ukritisk at optage den gængse nationaløkonomiske betragtningsmåde. I stedet for at bestemme konkurrence og konkurrenceevne overhovedet kaster de sig lige ud i de specielle sider af konkurrencen - nemlig udenrigskonkurrencen. Man udnævner de brancher, som producerer til hjemme- eller eksportmarkeder, hvor også udenlandske kapitaler er repræsenteret til »konkurrencesektoren«. På den måde ryger man med på den afledningsmanøvre, som DØR og andre borgerlige $\varnothing$ konomer ynder at benytte sig af: produktionsfællesskabet Danmark er i grunden harmonisk, hvis det ikke var for den konkurrence, som vi påtvinges udefra. ${ }^{8}$

S.Ø. bestemmer rigtig nok, at konkurrenceevnen har sit udspring i dannelsen af de enkelte virksomheders markedsproduktionspriser (s. 8-9), d.v.s. i profitten pr. produceret enhed, restsummen mellem varens omkostninger og markedsprisen. De fremfører derfor også helt korrekt, at konkurrenceevnen bestemmes mere kompliceret end DØR giver udtryk for, idet nemlig afskrivninger på bygninger og maskiner, materialeudgifter, låne- og beskatningsvilkår samt arbejdsproduktivitet indgår ved siden af lønnen i bestemmelsen af den disponible nettoprofit. De når også frem til noget der kan ligne begrebet om den faldende profitrate: »profitklemmen « mellem omkostningerne pr. produceret enhed og den gennemsnitlige markedspris (markedsværdien). Men i kritikken af DØR's modstilling af lønstigning og profitabilitet forbliver de fastspændt i udenrigshandelsbetragtningen:

8. Den borgerlige nationaløkonomis apologetiske funktion træder her kun alt for tydeligt frem. Den nationale stat og dens teoretiske legitimation peger med den ene hånd mod horisonten, mens den med den anden dræner arbejderklassens konsumfond ud over dens i forvejen begrænsede omfang.

Blandt de ideologiske »subsumtionsformer«, hvori borgerskabet forsøger at inddæmme og forhindre en radikalisering af arbejderklassen hører - som utallige historiske erfaringer viser - netop »Nationen «, »Folket « og »Staten « sammen med »Partiet « og »Fagforeningen « til de mere formfaste. Den af merkantilismen og den tidlige kapitalisme frembragte national økonomi underst $\varnothing$ tter klart disse forestillinger. 
»Selv om dette ('profitklemmen') kan være en medvirkende forklaring på den nuværende internationale krise, har det ikke noget med konkurrenceevnen at gøre, for krisen rammer jo også de udenlandske virksomheder. Det er værd at slå fast - ikke mindst fordi det er noget uklart, hvornår DØR taler om krisen og hvornår om konkurrenceevnen.

Hvis derfor profitten i konkurrencesektorens virksomheder har nogen betydning for konkurrenceevnen må det være profitniveauet relativt til de udenlandske virksomheders profitter.« (S.Ø. s.9)

I stedet for at problematisere og afvise vismændenes sætten de relative verdensmarkedsforhold i centrum foretrækker Socialistiske Økonomer at justere og finpudse denne betragtningsmåde. I stedet for at påvise, at DØR ikke kan forklare sammenhængen mellem krise og konkurrenceevne, postuleres det fejlagtigt at der slet ikke eksisterer nogen sammenhæng.

Profitten sættes altså i en helt misvisende relation. I stedet for at måle den danske profit på den danske kapital og således nå til profitraten som afgørende i konkurrencen og som motor i den såkaldte konkurrenceevne, så sættes den i relation til den udenlandske profit. Profitraten eller »profitniveauet« bliver således ikke i sig selv betragtet som det centrale, men i stedet de relative profitrater.

Hvis man havde talt om konkurrencen overhovedet og herfra havde erkendt, at der også eksisterer indenlandsk konkurrence, at alle sektorer er konkurrencesektorer og at det faktum at nogle af disse også indgår i udenrigskonkurrence blot er en ydre, skærpende omstændighed, så ville kritikken af DØR have set noget anderledes ud. Det viser sig nemlig, at DØR's tilsyneladende fixering af de ydre relationer og sammenligninger blot er en finesse, som tjener til at forklare de indenlandske sammenhænge (mellem danske omkostninger og danske priser) i indirekte og fordrejet form.

I og med at S.Ø. falder for denne finte i den traditionelle nationaløkonomiske betragtningsmåde mister deres kritik af DØR sine potenser. Selvom det skulle lykkes dem at tilbagevise, at dansk økonomi relativt skulle være dårligere stillet end udlandet, så ændrer det ikke ved vismændenes tese om den omkostningsbestemte forringelse af enkeltkapitalernes konkurrenceevne mere generelt.

Jo mere den internationale overakkumulation trænger sig på desto større bliver de 'fixe' omkostningers belastning i produktionspriserne, og det gælder uanset om de $g \varnothing r$ det mere for nogle nationer end andre. Vismændenes fejl er ikke at de bringer dette til udtryk, men at de gør det på en falsk måde. De Socialistiske Økonomers fejl er at de tror at have manet vismændene i jorden ved at afsløre deres falske og misvisende argumentation.

Ved ensidigt at hæfte sig ved de specielle relative konkurrenceforhold i udenrigshandlen kan S.Ø. vise at det går relativt godt. Det gør de ved at vise at det går gennemsnitligt, måske en smule over gennemsnittet. Men de glemmer derved, at den gennemsnitlige tendens er at det går absolut ad helvede til for kapitalen, at omkostningsskruen er forbandet reel for kapitalen i alle sfærer af konkurrencen.

M.h.t. markedsandele, som i S.Ø.'s upræcise definition af konkurrenceevnen er en afgørende indikator, fremlægger de s. 16-25 en lang række beregninger, som kort og godt går ud på at 
»der ikke synes at være tegn på, at dansk industri har haft et systematisk fald i markedsandelene, hverken på hjemmemarkedet eller på eksportmarkederne. Der er således heller ikke noget, der tyder på, at dansk industris konkurrenceevne er blevet svækket i denne periode...« (S.Ø. s. 25).

»Fra 1973 til 1974 og fra 1974 til 1975 øges Danmarks verdensmarkedsandel. Dansk eksport har således her klaret sig bedre end eksporten fra vore konkurrenter. Og for 1975-76 forudser OECD en uændret verdensmarkedsandel for dansk eksport.

Vi må følgelig tilbagevise den udbredte opfattelse af, at dansk eksport ikke kan klare sig internationalt som følge af den danske omkostningsudvikling. Vi finder ingen tegn på, at dansk industris konkurrenceevne systematisk skulle være blevet ringere siden 1964. Specielt gælder det, at Danmark har klaret sig bedre end sine konkurrenter under den internationale krise i 1974-76.« (S.Ø. s. 23-24).

Denne kritiske afvisning af den gængse opfattelse på den borgerlige økonomis eget grundlag hører selvfølgelig til de positive punkter hos S.Ø. Men den lider altså af den skavank, at den udelukkende betragter konkurrenceevnen og markedsandelene relativt. Den internationale krise er jo netop tegn på, at der generelt er sket absolut forringelse af de konkurrerende kapitalers rentabilitet, at akkumulationsdriften er aftaget og at følgelig vægten bag eller stabiliteten i nationernes 'konkurrenceevne' er aftaget i absolut forstand. At afvise DØR med en statistisk påvisning af, at dansk eksport i procent af verdenshandlen er uændret, er ikke det samme som at afvise problemerne i dansk industri når verdenskapitalismen er i krise. Når tilmed de absolutte tal for eksportvolumen utvetydigt viser en nedgang for såvel verdenshandlen som for dansk eksport skal man være borgerlig økonom for ikke at se at der er en sammenhæng mellem krise og konkurrenceevne. At danske eksportvirksomheder (og enkeltkapitaler overhovedet - såvel i Danmark som i udlandet) kan have uændret eller sågar forbedret konkurrenceevne og samtidig blive tvunget til at dreje nøglen er ikke så lidt af et paradoks.

Foreløbigt kan vi sammenfatte, at S.Ø. har ret i, at det borgerlige begreb: »konkurrenceevne« er et upræcist og diffust udtryk for kapitalens sundhedsmæssige tilstand.

For det første hæftes det fejlagtigt kun ved udenrigshandlen, et særligt aspekt ved de nationale $\varnothing$ konomier. For det andet skelnes der ikke mellem absolut og relativ konkurrenceevne, hvorved der - som S.Ø. åbenbart fornemmer det hos DØR - sker en sammenrodning af vidt forskellige problemer.

De Socialistiske Økonomer gør intet til at afklare disse problemer, men koncentrerer sig om den relative konkurrenceevne. Deres tilgang er den rene empirismes, hvorfor begrebsdefinition er et spørgsmål om formel, postulatorisk subsumtion efter bekvemmelighedens princip.

For så vidt DØR's påstand om konkurrenceevneforringelse som følge af omkostningsstigninger udtrykker et problem i dansk privatkapitalisme generelt vedrørende den »absolutte« konkurrenceevne (forstået som den vægt/drift hvormed enkeltkapitalerne akkumulerer), så er S.Ø. kun med til at afklæde den dens falske formulering som et eksklusivt udenrigshandelsproblem. ${ }^{9}$

9. Distinktionerne her mellem henhv. 'almen' og 'særlig' konkurrence (altså mellem konkurrence overhovedet og den specielle udenrigskonkurrence) og 'absolut' og 'relativ' konkurrenceevne (d.v.s. 
Et andet punkt hos S.Ø. er deres kritik af, at DØR entydigt lader konkurrenceevnen, rentabiliteten eller profitraten være bestemt gennem lønomkostningerne. I den relle konkurrence bestemmes kostpriserne af den variable kapital plus den overførte konstante kapital pr. time delt ud på antallet af produktenheder; d.v.s. ud over lønnen kommer også materialeomkostninger, afskrivninger på bygninger og maskiner, rente- og skatteindhug i bruttoprofitten samt arbejdsproduktivitet og -intensitet $\mathrm{i}$ betragtning. Og dette så meget desto mere som den organiske sammensætning historisk er stigende med den fremadskridende akkumulation og bestandig formindsker det levende arbejde i forhold til det døde. De Socialistiske Økonomers kritik er altså - uden at de har begrebet den egentlige sammenhæng - korrekt på dette punkt.

Imidlertid gør de ikke rede for på hvilket grundlag vismændenes opfattelse skal ses. De forstår derfor heller ikke hvor godt og grundigt DØR's vulgærøkonomi er forankret i den kapitalistiske virkelighed. Forklaringen på DØR's vildfarelser forbliver derfor abstrakt: vismændene har valgt at forsvare The Establishment og kapitalen er jo altid interesseret $\mathrm{i}$ at knægte arbejderne.

Men hvis man undersøger sagen nærmere, så er det klart, at den simple modstilling mellem løn og profit er forbandet reel for de praktisk agerende enkeltkapitalister. For den produktive enkeltkapitalist er alle de faktorer som S.Ø. opregner nemlig givne betingelser, som han ikke kan bortabstrahere eller overskride: arbejdsproduktivitet, afskrivninger på bygninger og maskiner, låne- og rentevilkår samt det gennemsnitlige markedsprisniveau er givne størrelser og hans profitlogik er i denne fase af hans omslagscyklus fuldstændig identisk med en udbytningslogik overfor arbejderne. ${ }^{10}$ Når vi ser bort fra de begrænsede muligheder for $\varnothing$ konomisering med den konstante kapital bliver lønreduktion og intensivering af arbejdet den eneste måde hvorpå han kan forbedre sin individuelle produktions-

mellem enkeltkapitalen i sig selv og dens ydre relation til en anden enkeltkapital) er udelukkende formelle og anskuelsespraktiske sondringer. S.Ø.'s betragtninger må anses for så usammenhængende, at det dels ikke er umagen værd og dels ikke er videre befordrende at benytte dem som udgangspunkt for en kritik af konkurrencebegrebet i den borgerlige økonomi. Andre borgerlige $\emptyset$ konomer vil være at foretrække. Vi vil nøjes med at minde om at »Konkurrencen overhovedet, dette væsentlige lokomotiv i den borgerlige $\varnothing$ konomi, etablerer ikke sine love, men er deres eksekutor ... Konkurrencen forklarer derfor ikke disse love, men lader dem komme til syne, producerer dem ikke.«Marx, Grundrisse... s. 450.

Varepriserne er derfor ikke, som hos DØR og S.Ø. bestemt som en sammenstykning af omkostningsfaktorer, men af deres indhold af genstandsgjort samfundsmæssigt arbejde; omkostningsfaktorsammenhængene er blot den ydre form, hvori værdiforholdene og - bevægelserne eksekveres.

10. Derfor er Marx's abstraktion om lovene for kapitalen i almenhed, merværdi- og merværdiratebestemmelserne som det almene og væsentlige ved den kapitalistiske produktion, både abstrakt og konkretempirisk. Når nemlig den enkelte kapital betragtes isoleret, i abstraktion fra dens reelle forholden sig som enkeltkapital blandt andre enkeltkapitaler, har vi kun dens egen væsentlige logik tilbage.

Når de borgerlige økonomer bevidst eller ubevidst reducerer denne til en modsætning mellem løn og profit er der 'kun' springet tilbage til værdiforholdene at gøre, nemlig til forholdet mellem nødvendigt arbejde og merarbejde. S.Ø.'s fag økonomiske detaljekærlighed er i denne henseende en bevægelse bort fra det springende punkt og ud i konkurrencens illusioner. 
pris og dermed sine profitmuligheder. På de altid givne produktionsbetingelser er vismændenes betragtning altså den eneste umiddelbart rigtige. (Vulgærøkonomi er netop kendetegnet ved at være enkeltkapitalisternes generaliserede konkurrenceerfaring). Investeringer i nyt maskineri, produktivitetsforbedringer, ændringer i låne- og rentevilkår o.a., som S.Ø. og andre 'progressive' venstrefløjsfolk foreskriver, er begivenheder, som kun kan finde sted på et bestemt punkt i kapitalens omslag. Disse strategier, som satser på produktivitetsforbedringer, strukturrationaliseringer o.lign., har derfor deres begrænsning $i$ at de ikke uden videre lader sig realisere. Enkeltkapitalerne må først frigøre sig af deres nuværende stoflige binding før springet til et nyt produktionsniveau kan finde sted. De må gå den seje vej gennem stykvis overførsel af fixkapital til vareform, gøre det dramatiske spring til pengeform og herfra skride til amortisering og fondsdannelse. ${ }^{11} \mathrm{Og}$ en afgørende forudsætning for at der herefter sker konkurrenceforbedrende investeringer fra den ledige kapitals side er, at den allerede beskæftigede kapital i pågældende branche udviser en tilfredsstillende rentabilitet. Og det er i dette kernepunkt DØR tager sit strategiske udgangspunkt, når det gælder om at forøge den danske eksport.

Men dette er S.Ø. ikke enig i. De har så travlt med at hævde det stik modsatte af vismændene, at de erklærer det for en tvivlsom tankegang (S.Ø. s. 11), at større profitter skulle være det ledende motiv i kapitalbevægelserne. De Socialistiske Økonomer synes at mene, at hvis man belønner kapitalen for godt, så bliver den doven og inaktiv og den vil så undlade produktivitetsforøgende investeringer. Produktivitetsforbedringer skyldes ifølge S.Ø. snarere faldende profitabilitet.

Hvis spørgsmålet alment havde drejet sig om produktivitetsudvikling måtte vi sige at S.Ø. her har ret. Produktivitetsudviklingen fører pg.a. den stigende organiske sammensætning til et fald i profitraten, hvilket på sin side tvinger yderligere investeringer i forbedret teknologi igennem for at få del i ekstraprofitterne. Men det er netop ikke denne almene lovmæssighed, som diskuteres mellem S.Ø. og DØR, når de udvælger en bestemt sektor af økonomien. Her er det sådan, at svigtende profitabilitet ganske vist fremskynder den moralske forældelse af kapitalapparatet, men på en sådan måde, at kapitalen vandrer bort fra branchen. Hvis diskussionen skal stå omkring handels- og betalingsbalanceproblemet, så må vi give vismændene ret i deres antagelse af, at en forhøjelse af profitraten vil betyde en tilvandring af yderligere kapital til eksportsektoren og nyanlæg plejer jo at være de mest moderne.

11. At dette er en særdeles lovmæssig og uomgængelig proces illustreres gennem den fra industrien fremførte skepsis overfor lempelser i afskrivningsreglerne som mulig kapitalstøtte. At en forhøjelse af afskrivningsloftet kan virke accellererende på kapitalomslaget og dermed stimulerende på investeringerne må stærkt betvivles al den stund det ikke er muligt at udnytte de eksisterende afskrivningsmuligheder fuldt ud. 
Vi ser altså, at vismændenes strategi er den, som mest fundamentalt tager fat om den privatkapitalistiske konkurrenceøkonomis drivhjul, idet den tager udgangspunkt i den aktive produktivt bundne kapital og dens problemer. Den abstrakte holdning hos S.Ø., at kapitalen jo bare kan se at få forøget produktiviteten i stedet for at angribe arbejdslønnen forekommer på det grundlag som ren ønsketænkning uden hold i de aktuelle $\varnothing$ konomiske forhold.

\section{Lønberegningerne}

Vismændene har i deres aprilrapport s. 18 anført en tabel over en række forskellige nationers lønudvikling.

Efter som vismændene, som vi lige har set, har den eksisterende kapitalistiske produktion med dens rene udbytningslogik i centrum for deres betragtning har de også valgt at anføre lønomkostningen pr. arbejdstime og ikke pr. produktionsenhed.

Dette kan udtrykke to ting. For det første giver denne form for lønopgørelse den største procentstigning for Danmark, hvilket jo er et stærkt argument for den tilbageholdende indkomstpolitik. Den påståede merstigning i Danmark på hele $20 \%$ giver et fingerpeg om hvordan den ‘ $ø$ nskelige’ lønudvikling ser ud for vismændene og kapitalen fremover.

For det andet har denne opgørelse den finesse, at vi på denne måde får et billede af, hvorledes identiske enkeltkapitaler i forskellige nationer har haft større eller mindre stigninger i lønomkostninger og dermed - alt andet lige - omvendt mindre eller større profitter. Man kan blot tænke sig to kapitaler med samme produktionsapparat og samme produktionsomfang. Opgørelsen fra de svenske arbejdsgivere og de danske vismænd vil så vise udviklingen i de relative lønniveauer som en indikator for de relative merværdirater og profitrater.

Denne betragtning har imidlertid sine begrænsninger. For det første er forudsætningen omkring identiske enkeltkapitaler temmelig urealistisk og kan slet ikke bringes i anvendelse hvor der er tale om forskellige udviklingsgrader i kapitalisering og industrialisering i de sammenlignede lande. For det andet er det fuldstændigt tåbeligt at sammenligne de nationale gennemsnit; hvis man vil vide noget reelt om sammenhængen mellem lønudvikling og relativ konkurrenceevne må man gå branche- eller endda varespecifikt til værks og undersøge de helt konkrete forhold. Og for det tredie er udviklingen i virksomhedernes individuelle produktions betingelser kendetegnet ved at der sker en erstatning af levende arbejde med dødt arbejde, hvilket betyder dels en relativ aftagen i virksomhedens samlede lønomkostning og dels en relativ aftagen i lønnens genoptræden som kostpriselement i den enkelte vares produktionspris. Udviklingen i arbejdets produktivkraft som enkeltkapitalistisk middel til ekstraprofitter betyder en stigende organisk sammensætning, hvor den konstante kapital såvel overfor den samlede udlagte kapital som overfor den enkelte vares samlede salgspris får stadig større betydning. 
DØR's opgørelse af timelønsudviklingen på nationalt plan kan måske have interesse i helt andre sammenhænge, men er en ren vildledning når det gælder vurderingen af de internationale konkurrenceforhold.

Overfladisk set udvikler S.Ø. her en korrekt kritik af DØR: Opgørelser af timelønsudviklingen siger ikke noget reelt om udviklingen da den udelader produktivitetens betydning. S.Ø. fremlægger derfor en statistik fra det amerikanske arbejdsministerium, som angår lønudviklingen pr. produktionsenhed. Det viser sig i denne, at produktivitetsstigningen i dansk eksportindustri mere end opvejer den overgennemsnitlige timelønsudvikling, når man udregner de relative »enhedslønomkostninger «. Produktivitetsstigningen er altså ikke kun overgennemsnitlig, men overgennemsnitlig i en sådan grad, at det har kompenseret den overgennemsnitlige lønstigning. Hvis det er rigtigt må det videre betyde, at der indenfor det gennemsnitlige markedsprisniveau for danske eksportprodukter må være levnet et større rum for den danske eksportkapitals afskrivning og forrentning. Men dette er nok også nødvendigt eftersom den jo har haft den største produktivitetsudvikling og således må havde den største bestanddel af overført fixkapital i produktionsprisen.

Men alle sådanne spekulationer afhænger helt af de statistiske oplysninger fra det amerikanske arbejdsministerium. S.Ø.'s teoriløshed kommer her klart for dagen. I stedet for at begribe markedsprisdannelsen og således levere en videnskabelig kritik af DØR holder man sig til empirismens spekulationer. S.Ø. fremhæver ganske vist produktivitetens betydning, men ikke for at udvikle de $\varnothing$ konomiske lovmæssigheder, kun for at perfektionere den empiriske tilgang til lønproblemet. Bent Rold Andersen kan derfor også ånde lettet op og fremhæve den store usikkerhed, der altid er knyttet til produktivitetsmålinger. (Aktuelt d. 8. og 9. juni).

Det amerikanske arbejdsministerium skulle ifølge B.R.A. have benyttet en statistik for Danmark, som kun omfatter den egentlige industrielle virksomhed, mens materialet for de $\varnothing v$ rige lande tillige skulle omfatte mere håndværkspræget produktion. Pointen skulle altså være, at man sammenligner spidsen af den danske produktivitet med et mere gennemsnitligt produktivitetsniveau for de øvrige lande. Den relative danske produktivitetsudvikling skulle derved blive stærkt overvurderet.

B.R.A. har derfor udviklet en ny beregning (S.Ø. s. 30), hvori der vægtes for den betydning, som industrien har i udenrigshandlen, og hvor der udover den egentlige industri også anføres en beregning af industri plus håndværk.

Når disse vægte benyttes og når der korrigeres for valutakurser, så svinder de oprindelige $20 \%$ merstigning i timelønningerne ind til en merstigning på 3\% i »enhedslønomkostning « indenfor den egentlige industri. Men nu er den gode Rold Andersen nødt til at lave krumspring for ikke at tabe ansigt. Han hævder derfor uden videre, at når man korrigerer tallet på $3 \%$ for industrieksporten med den mere håndværksmæssige eksport, så bliver det til en merstigning $\mathrm{i}$ de gennemsnitlige »enhedslønomkostninger« på $21 \%$ eller $17 \%$ korrigeret for valutakurser. 
De socialistiske $\varnothing$ konomer kan her uden besvær påvise, at det må være det rene vrøvl. For blot at holde det internationale gennemsnit måtte man regne med en produktivitetsstigning på 0 indenfor håndværket. Og hvis den danske stigning $\mathrm{i}$ lønomkostning skulle være overgennemsnitlig måtte der være tale om en faldende produktivitet $\mathrm{i}$ dansk håndværk; en temmelig urimelig antagelse.

Alt i alt fører disse statistiske spekulationer til at S.Ø. fastholder, at lønomkostningen pr. produktenhed må have været lavere end gennemsnittet fra omkring 1965 til og siden 1973-74 har det været lige nøjagtig gennemsnitligt.

Hvad S.Ø. her har bidraget med er egentlig kun at have lokket vismændene længere ud på det skråplan som hedder teoriløs positivistisk fagøkonomi. De egentlige sammenhænge mellem lønudvikling, kapitalakkumulation og konkurrenceudvikling forsvinder i diskussioner omkring valget af årstal, matematiske vægte o.lign. Som en anden afsløring af DØR's vulgaritet siger S.Ø. videre, at en væsentlig årsag til eventuelle forskydninger i det relative omkostningsniveau i Danmark snarere må ses i valutapolitikken end i lønudviklingen. Forsøget på gennem 'slangesamarbejdet' at klistre sig fast ved det opadgående tyske imperie har medført en revaluering af den danske krone overfor en række tredielande, hvorved importvarerne på den ene side er blevet billigere og således mere konkurrencedygtige overfor hjemmeproduktionen og eksportvarerne på den anden side dyrere på de udenlandske markeder. I DØR's strategi skal konsekvenserne af en valutarisk halehængspolitik således læsses over på lønarbejderne ${ }^{12}$.

Med S.Ø.'s afsløringer af Bent Rold Andersens fortsatte manipulationer i Aktuelt har vi således fået åbenbaret den danske orakelinstitution som mester i fagøkonomisk bortforklaring.

\section{Begrebet »Strukturarbejdsløshed «}

Begrebet »struktur« er om muligt endnu mere mystisk end begrebet »konkurrenceevne «. I den traditionelle betydning betegner det den struktur, som den samlede produktion er sammensat i vurderet ud fra dens brugsværdiside. D.v.s. branche- og sektorsammensætning, såvel produktivitetsmæssigt som omfangsmæssigt. Strukturel arbejdsløshed betegner således et afkast af ledig arbejdskraft som følge af ændringer i strukturen i den samfundsmæssige produktionsproces.

12. Den netop gennemførte nedskrivning af den danske krone i forhold til valutaerne i det europæiske akkumulationscenter har i denne forbindelse en ganske skærpende virkning på den indkomstpolitiske rammeaftale i augustforliget. Mens man fra statens side laver aftaler (med sig selv) om den formelle side af sagen: de nominelle pengelønninger, ordner den internationale kapital resten gennem den inflatoriske udhuling af lønningerne. Med denne skærpelse af augustforliget ad ekstraparlamentarisk vej skærpes også et af de afgørende problemer i vinter og til foråret: er det muligt for fagbevægelsen at dukke hovedet under den udspændte snor og samtidig fastholde den socialdemokratiske dominans. 
Men problemet er så hvorledes denne frisætning af arbejdskraft i et mønster svarende til »strukturudviklingen « i kapitalens materielle produktionsproces skal forklares. Her plejer folk så at tale om »strukturelle årsager«, d.v.s. forklare den branche- og sektorvise arbejdsløshed med den branche- og sektorvise udvikling i totalproduktionen. D.v.s. man forklarer egentlig strukturproblemet gennem en empirisk diskussion af det samme problem blot set fra den anden side. En sådan simpel positivistisk konstatering forklarer i og for sig ikke noget som helst. I stedet for at forklare arbejdsløsheden overhovedet begrænser man sig til at beskrive den.

På dette punkt fremfører vismændene i deres aprilrapport en argumentation, som faktisk må siges at være rimelig god. Deres forklaring er faktisk så avanceret, at de Socialistiske Økonomer har vanskeligt ved at følge med.

Vismændene kritiserer den gængse måde at diskutere strukturproblemer på. Fra nogles side (eksempelvis svenskeren Anders Östlind, se DØR s. 51) har det været tesen, at bag de strukturelle problemer omkring forbrugs- og efterspørgselsmønster, tekniske og produktivitetsmæssige problemer o.s.v. skulle det afgørende være lønkampen. Arbejderne skulle med deres umådeholdne lønhamstring selv være årsag til arbejdsløsheden. Der skulle være tale om en frivillig arbejdsløshed, d.v.s. man betragter den samlede lønmasse som en konstant, hvor så højere løn må betyde færre beskæftigede og omvendt (altså en slags ligevægtsmodel). Denne betragtningsmåde - som er temmelig udbredt i den borgerlige økonomi - fors $\varnothing$ ger altså at komme om bag de umiddelbart konstaterbare struktursammenhænge.

Vismændene afviser nu såvel den blot konstaterede forklaring på arbejdsløsheden som Anders Östlind (og herigennem også andre med mere eller mindre samme opfattelse).

»Ifølge analysen i de tidligere kapitler ligger hovedårsagen til den helt ændrede internationale beskæftigelsessituation i de sidste par år imidlertid ikke i sådanne strukturelt betonede forhold, men i en bevidst tilbageholdenhed i den $\varnothing$ konomiske politik i de lande, som i særlig grad er bestemmende for det internationale konjunkturforløb.« (DøR s. 51).

Umiddelbart ville man sige at dette er det rene vrøvl. Arbejdsløsheden tilskrives her den $\varnothing$ konomiske politik i stedet for den kapitalistiske $\varnothing$ konomi. Der ligger her en påstand om at den internationale krise er politisk forårsaget, nemlig af politisk tilbageholdenhed. Men når dette er konstateret og når vi renser udsagnet for dets vulgærkeynesianske element bliver kernen tilbage: arbejdsløsheden er resultat af den $\varnothing$ konomiske krise og de såkaldte »strukturproblemer « er økonomiske problemer snarere end tekniske. Årsagen til arbejdsløsheden er således $\varnothing$ konomisk i dobbelt forstand. På den ene side må der gives en $\varnothing$ konomisk forklaring på at der frisættes arbejdere og på den anden side må der gives en $\emptyset$ konomisk forklaring på at de ikke genoptages i produktionen.

På dette punkt fremfører DØR en kriseforklaring, som faktisk er i overensstemmelse med den Marx'ske akkumulationsteori. Blot udtrykkes den fordrejet og vulgært ud fra den produktive enkeltkapitalists standpunkt. 
Som nævnt tidligere deler DØR den ricardianske forsimpling af $\varnothing$ konomien til en modstilling af $l ø n$ og profit. Den rationelle kerne i denne opfattelse er, at den udtrykker enkeltkapitalistens forudsætninger: den konstante kapital, produktionsapparatet, er allerede købt og derfor fix; lånene er foretaget og renten er derfor også givet; produktivitet, afskrivninger, rente o.lign. er, som Altvater m.fl. siger i deres inflationsartikel ${ }^{13}$, 'fixe omkostningselementer'. Indenfor fixkapitalens omslag og lånekapitalens amortiseringsperiode kan der kun rokkes ved den flydende kapital, d.v.s. den som slår om flere gange i produktionsapparatets levetid. De løbende materialeudgifter anser enkeltkapitalisten også indenfor visse grænser som sat i konkurrencen uden for hans kontrol. For enkeltkapitalisten og DØR ser det derfor ud som om lønstigninger indenfor fixkapitalens levetid

»fremskynder det tidspunkt, hvor den bruttoindtjening, man får af en maskine eller et anlæg, ikke længere er tilstrækkelig til at dække lønomkostningerne, og hvor produktionen derfor bliver urentabel. Resultatet bliver altså en hurtigere $\varnothing$ konomisk forældelse af kapitalapparatet. Da nye årgange af kapital på grund af tekniske fremskridt kræver mindre indsats af arbejdskraft pr. produceret enhed vil arbejdskraftforbruget $\mathrm{i}$ forhold til produktionen falde særlig stærkt i en periode, hvor kapitalapparatets levetid afkortes.

Det må tilføjes, at den hurtigere reallønstigning ikke blot betyder, at kapitalapparatets levetid reduceres. Installation af arbejdskraftsbesparende kapitaludstyr, hvis priser er bestemt i international konkurrence, vil blive forceret og virksomhedernes nettoindtjening vil alt andet lige blive mindre.« (DøR, s. 55-56).

Dette er faktisk helt i overensstemmelse med de generelle love for den kapitalistiske akkumulation. Mens det i den samlede akkumulationscyklus forholder sig sådan, at det er den kapitalistiske produktionsudvikling som regulerer udbud-efterspørgsselsforholdene på arbejdsmarkedet og således gør løncyklen til den afhængige variable, så vil det for de praktiske agenter i et bestemt udsnit af cyklen se ud som om det er de stigende lønninger, der vælter læsset. Med opnåelsen af den fulde beskæftigelse i løbet af akkumulationsopsvinget bliver lønstigningen den umiddelbare anledning til den faldende profitrate. De stadig mere sammenhobede og skærpede modsigelser omkring stigende organisk sammensætning og overakkumulation af kapital bliver udløst af stigende lønninger, tilfældige ændringer i prisen på den flydende konstante kapital o.lign.

Den moralske forældelse af kapitalapparatet indtræder pludseligt, og i en voldsom destruerende proces genskabes den industrielle reservearme. Alt afhængig af overakkumulationens aktuelle karakter på dette punkt, d.v.s. hvor stor en del af den endnu bundne fixkapital, der må opgives som forældet eller gennem list og fusk kan kastes over på andre, hvor stor en del af den spekulativt forcerede produktion der går til grunde og således likviderer rentekrævende lånekapital etc., vil krisen uddybes og nedsætte akkumulationstakten. Den nedsatte 'investeringstilbøjelighed' i stagnationen og den forøgede organiske sammensætning i den overlevende og nyanlagte produktion vil skabe en reservearmé, som for de borgerlige økonomer vil vise sig som et vedvarende, »strukturelt« problem.

13. Jvf. E. Altvater / J. Hoffmann / R. Künzel / W. Semmler: »Inflation und Krise der Kapitalverwertung «, Probleme des Klassenkampfs nr. 17 / 18. Oversat i: Inflation og Krise, Kurasje 1976. 
Reservearméens funktion er nu at konkurrere med sig selv og med den produktive armé, således at der sker et fald i det gennemsnitlige lønniveau, hvilket er identisk med en forøgelse af merværdiraten eller af merarbejdet, som er det grundlag, hvorpå akkumulationen igen kan tage fart. Sammen med kapitaldestruktionen bliver lønreduktionen den væsentligste løftestang for et nyt $\varnothing$ konomisk opsving. Og for så vidt den organiserede klassekamp er en hindring, må de $\varnothing$ konomiske lovmæssigheder antage politisk bevægelsesform, d.v.s. fastslås som lov.

Det Økonomiske Råd har ikke erkendt dette i videnskabelig forstand, men bragt det til udtryk af omstændighederne. ${ }^{14}$

Vores socialistiske fagøkonomer, som gerne vil kritisere vismændene, afslører i den korte kommentar til dette afsnit (som faktisk er det mest respektable hos DØR), at de ikke har forstået det halve af det. Den kendsgerning, at de er borgerlige $\emptyset$ konomer, slår her fuldt igennem. Deres hovedkritik ser således ud:

»Den alvorligste mangel ved DØR's uklare diskussion om strukturarbejdsløshed er, at de ikke drager klare og præcise konklusioner om, hvilken arbejdsmarkedspolitik der skulle føres, hvis arbejdsløsheden var forårsaget af en hurtigere teknologisk udvikling. Hurtigere strukturforandringer som følge af kortere levetid for kapitalapparatet fører nemlig til en bestemt sammensætning af de arbejdsløse. Arbejdsløsheden kan da kun fjernes gennem selektive indgreb, ofte gennem forskellige former for uddannelse.« (S.Ø. s. 46).

Mens vismændene er klare over, at opsugningen af den ledige arbejdskraft er et spørgsmål om genskabelsen af en tilfredsstillende $\varnothing$ konomi for kapitalen og derfor drager den »klare og præcise konklusion«, at den tilbageholdende indkomstpolitik må være den rette form for aktiv arbejdsmarkedspolitik, så tror de Socialistiske Fagøkonomer åbenbart, at det er et »strukturelt « problem omkring tilpasningen af kvalifikationer. Tilvejebringelsen af en $\varnothing$ get faglig mobilitet er imidlertid kun ydre rammebetingelser, som ikke plejer at volde de store problemer. Vismændene henviser her bl.a. til, at det var »relativt ubesværet « for erhvervslivet, at absorbere afvandringen fra landbruget og fra hjemmene i akkumulationsopsvinget. (DØR s. 57).

S.Ø. udviser altså her ligesom i løndiskussionen en total mangel på evne til at hæve sig fra den rent tekniske, stoflige bestemmelse af produktiviteten. De samfundsmæssige udviklingslove og-former, hvori den stoflige produktion foregår, er et lukket land for den borgerlige $\varnothing$ konomi.

14. At indkomstpolitikken pr. definition er beregnet på at være politisk bevægelsesform for de $\emptyset$ konomiske lovmæssigheder afsløres helt eksplicit hos DØR:

»Skepsis over for mulighederne herfor eller over for ønskeligheden af indkomstpolitik er ligeledes en medvirkende faktor til at man affinder sig med en betydelig arbejdsløshed. ... Kan der ikke etableres en tilbageholdende indkomstpolitik, som led i den samlede $\emptyset$ konomiske politik, kommer man vanskeligt uden om, at arbejdsløsheden har en funktion at udfylde $i$ systemer, der bygger på markedsøkonomi - nemlig at holde igen på inflationen.« (Dansk Økonomi, april - 76. s. 21-22, min fremhævelse). 


\section{Indkomst- eller lønpolitikken}

De Socialistiske Økonomers kritik af indkomstpolitikken og nedskæringspolitikken over for de offentlige udgifter er abstrakt taget korrekt: den er klart klassebestemt som overgreb mod arbejdernes levestandard.

Men som borgerlige $\varnothing$ konomer er de ude af stand til at give en materialistisk og samfundsmæssig forklaring på denne klassekarakter i den statslige politik. Deres kritik må derfor foregå på den måde, at de foregøgler at der findes andre former for statslig kriseløsning.

Den førte politik bliver således kritiseret for at være ineffektiv, endog kriseforlængende. Den statslige politik er ifølge S.Ø. mislykket og uacceptabel - ikke fordi der ikke gives nogen kriseløsning uden for den kapitalistiske produktionsproces, men fordi den er utilstrækkelig. Mens det må siges at være en fundamental bestemmelse ved staten i en privatkapitalistisk økonomi, at den ikke direkte kan løse problemerne, men kun sætte rammer, som letter kapitalens egen kriseløsning, så mener S.Ø. at der blot skal føres en mere aktiv politik, en konsekvent venstrekeynesiansk interventionspolitik, som gennemsætter den fulde beskæftigelse uden lønreduktion.

»Den manglende teoretiske overvejelse får her tydeligt til følge, at det hele ender i reformisme. Ikke forstået som politisk skældsord, men som udtryk for manglende evne til at se samfundet som kapitalistisk, d.v.s. et samfund hvor kapitalens iboende grænser også sætter grænserne for den økonomiske politik. Alle forestillinger om en alternativ politik kommer dermed til at svæve frit i luften som overbudspolitik a la DKP.« (Nils Bredsdorff, Politisk Revy nr. 274).

Det vil her være spild af tid at gennemgå alle de alternative forslag, som indgår i PØP, den progressive $\varnothing$ konomiske politik..$^{15}$ I stedet skal vi kort se på den specielle venstrekeynesianske form hvori de statscentralistiske tendenser udklækkes.

Man kan sige, at DØR udtrykker to forskellige standpunkter. På den ene side vil de gøre sig gældende som keynesianere i forhold til de monetaristiske tendenser, som udtrykkes af Milton Friedman og den såkaldte Chicagoskole og som har fundet praktisk- politisk nedslag i den vesttyske $\varnothing$ konomiske politik. På den anden side må de imidlertid forlade dette standpunkt og diskutere mere alvorlige problemer omkring den privatkapitalistiske markeds $ø$ konomis »naturlige « funktionalitet for at begrunde den nuværende krise.

Dette er ikke andet end det nødvendige udtryk for den vulgarisering af den keynesianske teoridannelse, som finder sted på dennes forfaldsstadie. Hos mesteren selv finder man i den kendte psykologisme omkring »den vigende investeringstilbøjelighed « hos kapitalisterne en kriseforklaring, som må siges at være respektabel for så vidt den bringer noget reelt til udtryk. Men hos eleverne ender vi i det helt

15. For en mere uddybet kritik bør man læse »Stabiliseringspolitik \& statskapitalisme«, H. J. Jensen/ J. Brinch/L. Hansen/ N. Bredsdorff, Politisk Revy nr. 298. 
absurde, det konsekvent idealistiske: den nuværende krise er forårsaget af en slags »vigende interventionstilbøjelighed « hos politikerne. ${ }^{16}$

Dette karakteriserer såvel DØR som S.Ø. Men som det her er forsøgt vist indeholder DØR's rapport også en mere besinding krisediskussion, idet de fors øger at bringe sammenhæng mellem omkostningsudvikling, rentabilitetsudvikling, produktivitetsudvikling og arbejdsløshed.

Hos S.Ø. derimod finder vi ikke noget som helst tegn på en fagøkonomisk selvkritik. De ulejliger sig ikke engang med at eksplicitere den keynesianske $\varnothing$ konomikonception, som vel er den eneste sammenholdsfaktor i PØР-programmet, i en samlet, konsistent fremstilling. De statscentralistiske tendenser i forslagene er derfor en ren eklektisk sammenstykning af ideer fra den keynesianske teori, det socialdemokratiske principprogram og venstrefløjspartiernes kriseløsningsstrategier.

Det skal her afslutningsvis konstateres, at som det gik DØR således gik det også S.Ø. Selv om det fors $\varnothing$ ges skjult i den »sociale ansvarlighed «s fraser viger heller ikke S.Ø. tilbage for at angribe arbejderklassens levestandard.

S.Ø. har forstået så meget af vismændenes prædiken, at de må indrømme, at det gælder om at begrænse forskellen mellem forbrug og produktion. Den grundlæggende arbejdsværditeoretiske sammenhæng mellem produktion og rigdom, som åbenbart piskes ind hos de borgerlige $\varnothing$ konomer gennem udenrigshandelsproblemerne, skal overholdes: importen skal begrænses og eksporten $\varnothing$ ges.

Blandt forslagene til imødegåelse af importstigninger finder vi følgende:

»Skatten på olie, benzin og andre importerede energiformer må være så høj, at der er en kraftig motivation til besparende foranstaltninger.« (S.Ø. s. 73).

At bilen i den højtudviklede kapitalisme er blevet en del af de nødvendige udgifter, som arbejderne må afholde ud af deres løn for at sikre deres geografiske mobilitet, at hovedparten af fyringsolie går til opvarmning af boliger og at videre el-udgiften er et væsentligt moment i husholdningen, synes S.Ø. helt at abstrahere fra.

Af andre forbrugsvarer, som må siges at være en del af det historisk tilkæmpede reproduktionsniveau for arbejderklassen i den højtudviklede kapitalisme, finder vi »fjernsyn, radioer, båndoptagere og forstærkere; fotografiapparater, smalfilmsapparater, lysbilledapparater og film; ure, smykker m.v.; chokolade.« (s. 74).

I følge Socialistiske Økonomer vil disse varer være en unødig luksus for den danske proletar. Udsigten for lønarbejderne er altså, at de må cykle på arbejde og hjem igen. Og hvis de ikke er så trætte at de falder i søvn, må de sidde og synge højskolesange ved stearinlys og strikke sokker og vanter til vinteren. Men denne proletariske tilværelse skal så kompenseres med fuld beskæftigelse, en forbedret reparationsservice, en forbedret uddeling af rykkerbreve, samhandel med Come-

16. Det er ikke uden munterhed at vi hos DØR (s. 28-29) kan læse at de tyske vismænd har betegnet det nuværende dilemma blandt fag økonomerne som en »renselseskrise for den $\emptyset$ konomiske politik. « 
con i stedet for EEC, arbejderkontrol med toiletforholdene og trækninger på den ubegrænsede kreditværdighed i udlandet.

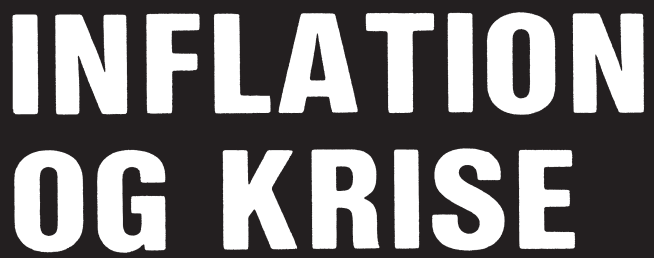

En antologi med følgende indhold:

Elmar Altvater, Jürgen Hoffmann, Rainer Künzel og Willi Semmler:

Inflation og kapitalvaloriseringens krise

Paul Mattick:

Den deflationare inflation

Olaf E. Dombrowsky:

Kritik af borgerlige inflationsteorier

Denne bog er det første dansksprogede materiale, som forklarer, hvorfor kapitalismens modsigelsesfulde udvikling i efterkrigstiden på trods af politisk inflationsbekæmpelse frembringer den nye inflation med såvel prisstigninger som arbejdsløshed og krise. Den viser dermed, hvorfor selv den mest gennemførte socialdemokratiske styring af kapitalismen må spille falit overfor kapitalismens modsigelser.

176 sider; kr. 30,-KURASJE 


\section{KURASJES BOGUDGIVELSER}

Altvater, Brinch m.f́.: Inflation og krise - En antologi 176 sider; kr. 30,-

Inger Bonnesen og Ane Thøger: Den kapitalistiske stat og dens funktioner. En bog om marxistisk statsteori 176 sider; kr. 22,--

Finn Hansson: Kapitalakkumulation, arbejderklasse og socialpolitik

95 sider; kr. 14,-

Introduktion til Kapitalens første bind. Nu trykt i 23.000 eksemplarer!

224 sider; kr. 18,-

Dieter Läpple: Staten og de almene produktionsbetingelser 144 sider; kr. 17,--

Paul Mattick: Krise og arbejdsløshed 120 sider; kr. 16,--

Paul Mattick: Kriser og kriseteorier 136 sider; kr. 17,--

Kurt Aagaard Nielsen: Kvalifikationsstruktur og klassestruktur 144 sider; kr. 24,--

Christel Neusüss: Imperialismen og det kapitalistiske verdensmarked

244 sider; kr. 35,-

Dieter Otten: Kapitaludvikling og kvalifikationsudvikling 200 sider; kr. 28,--

Eugen Pasukanis: Almen retslære og marxisme 124 sider; kr. 17,50

Helmut Reichelt: Kapitalbegrebets logiske struktur hos Karl Marx Udsolgt

Morten Thing: Ideologier og litteratur 142 sider; kr. 17,--

Bøgerne købes i bogladerne eller ved forudbetaling til KURASJE 